This item was submitted to Loughborough's Research Repository by the author.

Items in Figshare are protected by copyright, with all rights reserved, unless otherwise indicated.

\title{
Populism, anti-populism and crisis
}

\section{PLEASE CITE THE PUBLISHED VERSION}

https://doi.org/10.1057/s41296-017-0142-y

\section{PUBLISHER}

(c) Palgrave Macmillan

\section{VERSION}

AM (Accepted Manuscript)

\section{PUBLISHER STATEMENT}

This work is made available according to the conditions of the Creative Commons Attribution-NonCommercialNoDerivatives 4.0 International (CC BY-NC-ND 4.0) licence. Full details of this licence are available at: https://creativecommons.org/licenses/by-nc-nd/4.0/

\section{LICENCE}

CC BY-NC-ND 4.0

\section{REPOSITORY RECORD}

Stavrakakis, Yannis, Giorgos Katsambekis, Alexandros Kioupkiolis, Nikos Nikisianis, and Thomas Siomos. 2019. "Populism, Anti-populism and Crisis". figshare. https://hdl.handle.net/2134/31995. 


\title{
POPULISM, ANTI-POPULISM AND CRISIS
}

\section{Yannis Stavrakakis, Giorgos Katsambekis, Alexandros Kioupkiolis, Nikos Nikisianis \& Thomas Siomos}

School of Political Sciences, Aristotle University of Thessaloniki, Thessaloniki, 54124, Greece

\begin{abstract}
This article focuses on two issues involved in the formation and political trajectory of populist representations within political antagonism. First, it explores the role of crisis in the articulation of populist discourse. This problematic is far from new within theories of populism but has recently taken a new turn. We thus purport to reconsider the way populism and crisis are related, mapping the different modalities this relation can take and advancing further their theorization from the point of view of a discursive theory of the political, drawing primarily on the Essex School perspective initially developed by Ernesto Laclau and Chantal Mouffe. Second, this will involve focusing on the antagonistic language games developed around populist representations, something that has not attracted equal attention. Highlighting the need to study anti-populism together with populism, focusing on their mutual constitution, we will test the ensuing theoretical framework in an analysis of SYRIZA, a recent and, as a result, under-researched example of egalitarian, inclusionary populism emerging within the European crisis landscape.
\end{abstract}

Keywords: Anti-populism; crisis; discourse; populism; SYRIZA 
Research on populism has diachronically placed emphasis on the role of representation, no matter whether this is theorized in terms of a formal-discursive (Laclau, 1977; 2005a), structural (Canovan, 1999; 2005) or ideational manner (Mudde and Rovira Kaltwasser, 2012). Thus populism typically involves the activity of political agents (movements, parties, leaders, etc.) claiming to express popular interests and to represent associated identities and demands (the true will of the 'people') against an establishment, an elite, that undermines them and forestalls their satisfaction.

This paper focuses on two crucial issues involved in the formation and political trajectory of such representations within the framework of political antagonism:

1. On their conditions of possibility and, in particular, on the crucial if ambivalent role of crisis. This problematic is far from new within populism research but has recently taken a new turn beyond its many but limited existing articulations.

2. On the complex and antagonistic language games developed around such claims when different political actors attempt to come to terms, resolve and/or manipulate a crisis conjuncture. Such games can involve recognition and idealization, rejection and demonization of both 'the people' as well as of 'populism'. Perhaps surprisingly, this second rubric has not attracted equal attention.

Albeit brief references to the connection between crisis and populism abound in the relevant bibliography (Knight, 1998; Taggart, 2000; De la Torre, 2000), detailed treatments are rare and many of its aspects remain obscure. For example, 'crisis' is usually utilized in a taken-for-granted way that pays little attention to the gaps between what is perceived to be its 'objective' conditions and what could be seen as its 'social construction', i.e. its representation in populist discourse. Albeit 
much discussed in broader theoretical debates, this angle has not been adequately registered within populism research. The starting point of this paper is that no rigorous theorization of populist politics can proceed without further exploring the way populism and crisis are related, without, that is, theorizing the different modalities this relation can take (see, for a recent such attempt, Moffitt, 2015; also see Roberts, 2015). At the same time, it seems equally if not even more important to insist on studying anti-populism together with populism, focusing on their mutual constitution and reproduction. And not only on philosophical grounds, in a bid to register the importance of the irreducible dialectic between identity and difference (Saussure, 1959; Connolly, 1991). But also because populist discourses never operate in a vacuum and need to be situated within the context of political antagonism, within the broader hegemonic struggle, which is energized more often than not by crisis situations, real or/and imagined. This is impossible without focusing on the emerging populism/anti-populism frontier, and, in this context, it is a mystery why the 'important notion of anti-populism [...] has never really been studied or thematized as such' (Ostiguy, 2009, pp. 23-4).

We shall try, in this paper, to address both these issues - the role of crisis and the importance of the populism/anti-populism frontier - as well as to highlight the, often neglected yet revealing, interconnection between them. Addressing the first one requires one to raise the following line of questioning: How are crisis conjunctures related to populist phenomena? In particular, is it possible to account in an integrated way for both the Real as well as the Symbolic aspects of crises, for crisis as a trigger for as well as a construction of populist discourse? Our main hypothesis here is that theories of political discourse (Laclau) and cultural political economy (Sum \& Jessop) can greatly advance such an orientation. Addressing the second obliges us to pose a 
second set of questions: Are populist discourses the only ones that put forward their own constructions of crisis attributing the blame to what they portray as the establishment? What about the constructions of anti-populist discourses blaiming populism itself? Our second hypothesis is that a comprehensive theory of populism must be able to account for the complex choreography between populism and antipopulism in a rigorous way. These will be the main research questions orienting our inquiry and the main hypotheses explored.

The paper starts with a critical discussion of available models of analysis demonstrating significant lacunae and suggesting ways to effectively address them theoretically. The subsequent empirical analysis mainly focuses on Greece and the party formation of SYRIZA, a very recent and, as a result, under-researched case of contemporary populism emerging within a severe crisis conjuncture and thus offering a suitable example. We conclude by articulating a more comprehensive model linking together crisis, representation and the populism/anti-populism divide.

\section{Modalities of Crisis and Populism: Trigger or Performative Construction?}

\section{Conceptual background}

Like 'populism', ‘crisis' constitutes a complex and ambivalent concept. Originating from ancient Greek medical and juridical discourses (see Koselleck, 1988, p. 103; Perezous, 2007, p. 101), 'crisis' has historically signified both a critical conjuncture (a meaning emanating from medical discourse) and a final judgment (a sense originating from the juridical field). Moving into the 20th century, we encounter in the work of the Italian Marxist Antonio Gramsci the confluence between these two etymological 
origins of the term in a bid to account for political crises, crises of political meaning and orientation, beyond economic reductionism. As Gramsci, who had captured before anybody else the representational/discursive dimension of crises (Hay, 1999, p. 335), points out, '[i]t may be ruled out that immediate economic crises of themselves produce fundamental historical events; they can simply create a terrain more favourable to the dissemination of certain modes of thought, and certain ways of posing and resolving questions involving the entire subsequent development of national life' (Gramsci, 1971, p. 184). Indeed Gramsci's take manages to combine the problematics of crisis, representation, hegemony and mobilization, to which we shall return:

$[\mathrm{T}]$ he crisis of the ruling class's hegemony, $[\ldots]$ occurs either because the ruling class has failed in some major political undertaking for which it has requested, or forcibly extracted, the consent of the broad masses [...] or because huge masses [...] have passed suddenly from a state of political passivity to a certain activity, and put forward demands which taken together, albeit not organically formulated, add up to a revolution. A 'crisis of authority' is spoken of: this is precisely the crisis of hegemony, or general crisis of the State (Gramsci, 1971, p. 210).

Last but not least, Gramsci highlights the ambivalent and largely open character of the outcomes of crisis, formulating the oft-quoted phrase that crisis 'consists precisely in the fact that the old is dying and the new cannot be born' (Gramsci 1971, p. 276; also see Koselleck, 1988, p. 127).

More recently, within the field of political science, many of the aforementioned characteristics of crisis have been rigorously restated and further developed by Colin Hay. Hay is right when, partly drawing on Kosseleck, he locates within 'crisis' the 
cohabitation of two distinct dimensions, that of objective contradiction leading a given system into a phase of instability with unpredictable consequences, on the one hand, and that of subjective intervention which signifies and represents this instability in particular ways. While objectivist conceptions of crisis tend to obscure this dual and ambiguous character, Hay attempts to underline it by clearly distinguishing systemic contradictions or failures, that is to say condensations of such contradictions, and crises understood as decisive interventions on behalf of a variety of social actors through which these contradictions are identified, highlighted and meaningfully represented (Hay, 1999, p. 323).

Within the populism literature, associations between crisis conjunctures and the emergence of populist discourses and movements is a common place. The connection between periods of crisis and the development of populist reactions has been amply discussed within the populism literature (for a starting point, see Taggart, 2000 , pp. 2, 4-5, 93-94, 117). Indeed most analyses of populist phenomena claim that they emerge within a crisis context (de la Torre and Arnson, 2013, p. 18). Furthermore, this is something that seems to bridge mainstream approaches like the one put forward by Taggart with heterodox ones such as the one put forward by Ernesto Laclau. In the words of the latter: 'the emergence of populism is historically linked to a crisis of the dominant ideological discourse, which in turn is part of more general social crisis' (Laclau, 1977, p. 175; also see Moffitt, 2015, p. 191). With regards to peronism, the former adds that the invocation of a sense of crisis has played an important role in peronism and has highlighted the importance of leadership (Taggart, 2000, p. 66). In this sense, as Tormey and Moffitt have concluded, populism draws from the crisis context, which it highlights, translating it into a call for direct and decisive action able to promise the resolution of the problem at hand, whether this 
is about the collapse of trust between the citizenry and its elected representatives, or about any number of other grievances: immigration, social injustice, etc. (Moffitt and Tormey, 2014, pp. 391-2; also see Roberts, 1995). And yet, does that mean that populism is exclusively associated with a pre-existing crisis? Or is it simply the case that a crisis can often benefit its development and wider political appeal? And how does that happen? Indeed, some commentators conceive of the connection between crisis and populism as a general tendency, but not as a determining condition or an essential criterion (Knight, 1998, p. 227; also see de la Torre, 2000, pp. 115-119). At any rate, the links between populism and crisis have not been adequately explored and theorized (Moffitt, 2015, p. 189).

Very recently, Moffitt has critically revisited this body of work, introducing what has been presented as a novel take on crisis and populism that stresses the ways in which populist discourse is not merely a response to a pre-existing crisis, but also an active (performative) creator of 'crisis' at the level of representation, where its defining caracteristics are socially and discursively constructed (Moffitt, 2015; also see Moffitt, 2016). Summarizing the ongoing debate, we can introduce the following typology of the main existing approaches.

\section{Crisis as a triggering mechanism}

The most orthodox approach, cogently restated in recent years by Kenneth Roberts (Roberts, 2015), highlights the multiple ways in which a crisis situation operates to trigger populist mobilization. Of course, it is not any crisis, but a crisis of representation that is of interest here: 'populism thus emerges as a probable - though hardly an inevitable or exclusive - political strategy for appealing to mass 
constituencies where representative institutions are weak or discredited, and where various forms of social exclusions or political marginalization leave citizens alienated from such institutions' (Roberts, 2015, p. 141).

Against such a crisis background, the appeal of populist discourse lies in its ability to connect anti-elite and anti-establishment discursive calls (supply side) to 'the political mobilization of the excluded and the alienated [demand side] - that is, to inspire popular subjects to rally, to protest, to strike, to organize, and/or to vote' (Roberts, 2015, p. 142). Roberts goes on to distinguish between different types of such representation crises on the basis of the degree of institutional consolidation pertaining to different political cultures and national contexts, offering a variety of examples from the Argentinian crisis of 2001-2 to developments in Venezuela leading up to the Chavez phenomenon (Roberts, 2015, pp. 147-150). What is important, from our point of view, is that crisis clearly pre-exists a populist mobilization, which is conditioned by it. In other words, populism cannot make its presence felt before such a systemic failure starts short-circuiting the effective democratic representation of social interests, values and demands in the decision-making process through established parties and other intermediary organizations (Roberts, 2015, p. 147).

\section{Crisis as a performative construction}

Although Roberts repeatedly stresses the importance of representation (and its crisis) in accounting for populist phenomena, his understanding of 'representation' is a standard political science one, in which representation should be examined in dialogue with 'the analysis of political parties, civil society, and social movements' (Roberts, 2015, p. 155). This politically focused understanding of representation has 
recently been shown as inadequate by Benjamin Moffitt (Moffitt, 2015). No doubt, Moffitt acknowledges the importance of the literature correlating populism with crisis; at the same time, he locates in it serious shortcomings. In particular, in his view, to conceptualize populism and crisis in external terms, to see crisis as an external triggering mechanism or a necessary pre-condition, does not allow political analysis register and reflect on the internal linkages between crisis and populism at the performative level. Hence, Moffitt insists on the importance of crisis as an essential (internal) characteristic of populism. Questioning the externality between the two (Moffitt, 2015, p. 211), he places emphasis on the performative construction of crisis by populist discourse itself: 'if we do not have the performance of crisis, we do not have populism' (Moffitt, 2015, p. 190). Here representation is primarily conceived in terms of symbolic articulation and performance.

In short, Moffitt identifies two important issues. First, crisis is never experienced as something given, obeying a simple causal explanation. Second, crisis never becomes accessible for us in some 'objective' and 'neutral' manner. The real of the crisis can only become (partially) accessible through some kind of mediation, through its performative construction by populist discourse. Here Moffitt directly refers to the Lacanian distinction between the Real and the Symbolic: 'To more widely invoke Slavoj Žižek's (1999) reading of Lacan - there may very well be a Real in which crisis operates, but we cannot access it because our language remains at the level of the Symbolic. As such, crisis is very much what we make of it'. What this means is that, ultimately, 'populist actors actively perform and perpetuate a sense of crisis, rather than simply reacting to external crisis' (Moffitt, 2015, p. 195). Thus, Moffitt's approach concludes that crises are never 'neutral' phenomena, but involve complex mediations 'performed' by certain political actors: 'populist actors actively 
participate in the "spectacularization of failure" that underlies crisis, allowing them to pit "the people" against a dangerous other, radically simplify the terms and terrain of political debate and advocate strong leadership and quick political action to stave off or solve the impending crisis' (Moffitt, 2015, p. 198; also see Moffitt, 2016, p. 113132).

\section{Bridging the Gap: Dislocation, Radical Constructionism and Performativity}

Moffitt's systematization of the debate is helpful and topical. However, it relies on the staging of certain oppositions that may partially obscure what is at stake, instead of fully illuminating it. On the one hand, he does register the fact that the two approaches to the relationship between crisis and populism are not mutually exclusive. Arguably, without a real systemic blockage, a collapse of trust and a failure within established modes of representation, there is no space created for political outsiders/newcomers to put forward their supposedly superior claim to represent (to voice) the frustrated popular will in a potentially hegemonic way. And yet, Moffitt is correct to question a simplistic view that would posit some sort of automatic causal link between 'objective' crisis and populism. As we have seen, Gramsci and, even more clearly, Colin Hay, have highlighted the importance of mediating mechanisms beyond 'objective' conditions. Moffitt himself refers to Colin Hay's work, which has highlighted the importance of constructions of the 'crisis' beyond any systemic 'failure' that pre-exists (Moffitt, 2015, p. 197):

crisis and failure simply cannot be equated. Crises are representations, and hence 'constructions' of failure. [...] Such perceived and identified failures thus form the basis for contested and competing constructions and 
mediations of crisis which attempt to find and construct resonance with individuals' and groups' experiences of the symptoms of failure (Hay, 1995, p. 68).

In this sense, Moffitt's work seems to be summarizing a long tradition arguing that systemic failure and 'crisis' - that is to say crisis narratives - are not to be confused with each other. And, of course, one should also add here that such constructions are not the exclusive privilege of populist political actors. Interestingly enough, Hay emphasizes the way the thatcherite New Right has constructed the so-called 'winter of discontent' through a particular narration of state and economic failure, which prioritized neoliberal solutions (Hay, 1995, p. 71).

Apart from summarizing a whole theoretical tradition, the added value here is obviously the application of this rationale in the analysis of populism (Moffitt, 2015, p. 208). And yet, performing this leap seems to presuppose a certain casualty. Indeed, one cannot help but be struck by the way Moffitt positions Laclau's contribution to this debate on the side of the supposed defenders of 'external', 'objective' crisis as a trigger for populism (Moffitt, 2016, p. 115). What is ignored here is, firstly, Laclau's social constructionist emphasis on discourse, beyond any objectivist rationale. Second, and most importantly, the way in which, already from 1990 and through a debate with Zizek on the Lacanian Real - which, as we have seen, Moffitt cites as one of his own main inspirations - Laclau will introduce the concept of 'dislocation' as the (inherent) limit of (socially constructed) social objectivity, the moment of failure that ruptures our established reality and opens up an antagonistic play between competing discursive articulations struggling to impose a new hegemony (Laclau, 1990). Thus, together with Moffitt (and Lacan and Zizek), Laclau will accept the gap between Real (objectivity) and Symbolic (social construction), between 'failure' and 
'crisis' in Hay’s schema (Laclau, 2003; 2004). However, contra Moffitt, he will also register and conceptualize the continuous encounters between them, highlighting the inherent link between the two dimensions, something ranking low in Moffitt's priorities. This is a crucial perspective, recently highlighted by cultural political economy as well: 'crises offer a real-time laboratory to study the dialectic of semiosis and materiality' (Sum \& Jessop, 2013, p. 397).

Indeed, already from the early 1990s, Laclau had introduced - following a significant debate with Zizek - the concept of 'dislocation', the kernel of his argument in New Reflections (Laclau, 1990, pp. 39-60) and arguably his most important conceptual innovation throughout this whole decade (Stavrakakis, 2007, pp. 73-4). Here disclocation is first understood as the moment of failure and subversion of a system of representation. Although dislocations are embodying a radical negativity as encounters with the Real, they have no positive content (symbolic meaning) in themselves (Lacan) - and cannot be predicted by any kind of determinist philosophy of history (Gramsci), they have certain important consequences for our sociosymbolic reality. This is due to the fact that besides their negative character they also entail a positive, productive dimension. If, as Laclau puts it, on the one hand they threaten established identities, on the other, they introduce a lack of meaning that constitutes the foundation on which new identities are formed (Laclau, 1990, p. 39). In other words, if dislocations destabilize existing identifications and discourses, at the same time they trigger new constructions. The latter attempt to suture the dislocated structure by narrating the 'crisis' in a mythical way, thus legitimizing particular solutions against others within the struggle for hegemony (Laclau, 1990, pp. $63,65)$. 
This way, Laclau's take on the dual character of dislocation manages to link the two orientations we have encountered: a dislocation, the failure of a sedimented system of representation (in both its senses, the traditionally political used by scholars like Roberts and the more constructionist used by Moffitt), is presupposed as a triggering mechanism for new populist (and other) discursive constructions uniquely narrating its characteristics and offering distinct solutions. And yet, far from being determined by the 'objectivity' of the dislocatory situation, these new articulations (populist or other) involve radical antagonistic construction. In New Reflections, Laclau uses the example of the German economic crisis of the 1920s to illustrate these points with a historical example. This crisis had 'devastating effects for the middle classes' to the extent that it involved a 'generalized dislocation of traditional patterns of life'. The lack created by these dislocations played an important role in triggering the articulation of Nazi discourse and in increasing its hegemonic appeal: 'The National Socialist discourse emerged as a possible response to the crisis and offered a principle of intelligibility for the new situation' (Laclau, 1990, p. 65). Four points need to be highlighted here vis-à-vis Laclau's position: 1 . This discourse was only 'a possible response' and not the only response; 2 . The new orientation it offered, the new principle of intelligibility on account of which it purported to meaningfully frame the crisis and articulate appealing solutions, involved a mythical Arian fantasy and an extreme example of blame attribution: the demonization of the Jews; 3. This new intelligibility 'is not something that stemmed necessarily from the crisis itself' (Laclau, 1990, p. 65) - it involved processes of performative construction; 4. The catastrophic implications of the aforementioned example and the barbaric nature of Nazi ideology should not make us attribute this choreography between social dislocation, crisis narrative, mythical framing and blame attribution - a choreography 
implicating a plurality of competing actors - to some sort of 'essentially primitive' impulses akin to an 'outbreak of irrationality' (Laclau, 1990, p. 67). On the contrary, 'myth [as well as this whole dialectic] is constitutive of every possible society', of every discursive articulation with hegemonic pretensions (Laclau, 1990, p. 67): 'The welfare state, for example, was a myth aimed at reconstructing the operation of capitalist societies following the Great Deppression'.

Such constructions are radical because they involve retroactivity. Indeed, a radical retroactive ontology constitutes the cornerstone of Ernesto Laclau's theory of populism as formulated in his book On Populist Reason: 'the construction of the "people" is a radical one - one which constitutes social agents as such, and does not express a previously given unity of the group' (Laclau, 2005a, p. 118). The 'people' is always something retroactively constructed, an empty signifier that needs to be invoked, a call incarnated in a proper name that (partially) creates what it is supposed to be expressing (a sovereign collective identity). It is clear then that Laclau does not fit the side in which he is placed in the opposition between 'objectivists' and 'constructionists' Moffitt stages, between those that stress the 'externality' of crisis to populism and those, like Moffitt himself, who highlight their internal relation. Laclau's work is clearly located beyond such oppositions; by highlighting the political choreography between Real (dislocation) and Symbolic (articulation), between externality and internality, he arguably manages to advance a more nuanced account of populist politics.

Clearly indicative of such a rigorous and innovative orientation is the central place Laclau himself attributes to 'performativity' and the dimension of 'performance' in his late work on populism. Performativity is here registered as one of the attributes of the aforementioned radical construction (Laclau, 2005a, p. 103). In 
this schema, populist discourse always 'tries to operate performatively within a social reality which is to a large extent heterogeneous and fluctuating. I see this moment of vagueness and imprecision - which, it should be clear, does not have any pejorative connotation for me - as an essential component of any populist operation' (Laclau, 2005a, p. 118; emphasis added). Thus, already from 2005 Laclau had indeed put forward the 'foundations' of a performative theory of populism, ${ }^{1}$ in ways not far from the 'model' proposed by Moffitt. Social failure is constructed and performatively narrated as a crisis attributed to the action of an enemy (the oligarchy) simultaneously triggering the radical construction of the people :

If I refer to a set of social grievances, to widespread injustice, and attribute its source to the 'oligarchy', for instance, I am performing two interlinked operations: on the one hand, I am constituting the 'people' by finding the common identity of a set of social claims in their opposition to the oligarchy; on the other, the enemy ceases to be purely circumstantial and acquires more global dimensions. [...] we are dealing not with a conceptual operation of finding an abstract common feature underlying all social grievances, but with a performative operation constituting the chain as such (Laclau, 2005a, p. 97; emphasis added). ${ }^{2}$

\section{Enter Antagonism: Populism vs. Anti-populism}

One more important conclusion follows from this discussion. It is never only one political force that is engaged in the aforementioned hegemonic play, a single force performing - within a socio-political vacuum - its solipsistic staging of the crisis. And this is not merely an empirical observation. It follows from the irreducible gap itself 
between real failure and performatively constructed crisis highlighted up to now. This gap can be bridged in a variety of ways leading to the formation of antithetical political projects: 'various political forces can compete in their efforts to present their particular objectives as those which carry out the filling of that lack' (Laclau, 1996, p. 44). This is, after all, what hegemony is about, something also stressed by cultural political economy:

a crisis is a moment for contestation and struggle to construe it and inform individual and collective responses. This involves, among other issues, [...] identifying rightly or wrongly purported causes (agential, structural, discursive and technical) (Sum \& Jessop, 2013, p. 398).

Most available analyses of populism - including the one by Moffitt - ultimately fail to take into account this wider hegemonic environment within which populist actors have to operate. The latter are obviously never alone in identifying failures and in constructing crises by attributing blame and offering solutions. Most important, if they, quite often, invest on continuously propagating 'crisis', this strategy has to be placed within a wider antagonism between populism and anti-populism, which may result from the populist framing of the crisis but cannot be reduced to it. And here populists are not the only ones engaging in blame attribution, simplistic solutions and moral condemnation. ${ }^{3}$ How can populism research disavow the fact that 'crisis does not come pre-interpreted but is often profoundly disorienting, creating space for alternative, often contested, construals and crisis responses, with different subjects likely to adopt different stances'? (Sum \& Jessop, 2013, p. 396).

In fact, very often, the designation 'populist' - with all its historically sedimented negative connotations of irresponsibility, demagogy and/or antidemocratic tendencies - is attributed by mainstream parties and media to oppositional 
political forces and discourses - irrespective of their ideological orientation - in order to radically undermine their hegemonic potential. Whenever deep systemic failures and dislocations destabilize a hegemonic order, encouraging the dealignment of a party system on the basis of crisis constructions endangering its smooth reproduction, established forces put forward their own constructions of the crisis, disavowing all responsibility and - very often - identifying populism as the main root-cause. No doubt, '[s]uccessfully to blame one set of factors and/or actors deflects blame from oneself and sets the stage for efforts to resolve matters' (Sum \& Jessop, 2013, p. 399). What is also at stake in such blame attribution is the exact nature of the crisis: whether, that is to say, it will be designated as a 'crisis in' or a 'crisis of':

Crises 'of' a system are less common. They occur when there is a crisis of crisis management (i.e., normal responses no longer work) and efforts to defer or displace crises encounter growing resistance. Such crises are more disorienting than crises 'in', indicating the breakdown of previous regularities and an inability to 'go on in the old way' (Sum \& Jessop, 2013, p. 398).

Populist contenders usually portray the crisis as an internal 'crisis of' the previously hegemonic status quo (and its built-in crisis management apparatus), thus necessitating systemic renewal brough about by actors outside the crisis-ridden system (the populist contenders themselves). By contrast, established forces can only represent the crisis as a 'crisis in' the system, attributing the difficulties encountered in its management to predominantly 'external' factors, even if these factors can be also illustrated as having contaminated a system's internal functions: to the populist threat itself. 
At any rate, this antagonistic choreography obviously needs to be thoroughly registered within a comprehensive theory of populism. In fact, its continuous reemergence is far from coincidental within our political tradition. Throughout history, signifiers like 'the people' invariably function as markers of the internal division of every political community between part and whole, between the few and the many, those governing and those governed, those inside and those outside, those above and those below. This division seems to traverse the development of European if not global societies from Greek and Roman antiquity up until modernity, setting the stage for an often bitter political antagonism. Here, it is typically two sides that are involved and they can be equally vitriolic. The most classic illustration of this antagonism is offered by William Shakespeare in Coriolanus. Indeed, Shakespeare gives us both sides of the argument in their most extreme formulations. On the one hand, we have the patrician view of the people: there is talk, among others, of the 'beastly plebeians', surely a precursor of Burke's swinish multitude (3.1.66). On the other hand, we have the popular standpoint, with the accusations being directed towards the patricians (1.1.16).

The French Revolution constitutes a turning point here: through the elevation of the 'people' into the model of democratic political subjectivity it gives birth to two opposing modern traditions. One that recognizes the importance and, sometimes, even idealizes the people and another that stresses the dangers involved in mass mobilizations and, often, demonizes the people. In institutional terms this is translated into different models of modern democracy: discarding or embracing 'popular sovereignty', discouraging or encouraging popular participation, supporting democratic elitism (Schumpeter, 2003, pp. 284-5) or 'populistic democracy' (Dahl, 2006). During certain periods the clash between the two models, between populism 
and elitist anti-populism, subsides and (paradoxical) agonistic articulations emerge instituting a temporary truce; this is what Chantal Mouffe calls the democratic paradox (Mouffe, 2000). But the antagonism can always re-emerge, especially in times of systemic failure and crisis of representation. The pejorative designation 'populist' acquires increased importance within the language games marking such periods of democracy in crisis. Unable to openly castigate the people, within a political system still nominally founded on 'popular sovereingty', elitist forces attack 'populism', which is performatively constructed in a way condensing all democratic pathologies (crisis) and legitimizing elitist solutions, a claim to 'govern without the people' (Crouch, 2004; Ranciere, 2006).

At any rate, a rigorous theorization of populist politics will greatly benefit from placing emphasis on the antagonism between populist and anti-populist discourse and the way it shapes the identity of both emerging camps. As we know from Saussure, identity is impossible to formulate without difference: the meaning of a particular element within a system of signification can only arise via its differentiation from other elements within the same system: 'in language there are only differences' (Saussure, 1959, p. 120; also see Connolly, 1991, p. ix). In this light, to take into account the way populism and anti-populism mutually constitute each other should be considered an essential aspect of a constructionist, performative perspective on populism and crisis. Populism is inconceivable without anti-populism; it is impossible to effectively study the first without carefully examining the second. And yet, how helpful is such a hypothesis in analyzing particular empirical examples? 
The Greek Case: Crisis, Egalitarian Populism and Anti-populist Reaction in Southern Europe

\section{Crisis, articulation, polarization}

In many international contexts, economic and social dislocations (from Argentina's default in the early 2000s to the Greek debt crisis within the last few years) have triggered a crisis of representation that served as the springboard for a populist politicization. If the preceding argument is correct then the emergence of populist movements cannot be properly interpreted if one does not place them within the context of such failures of social reproduction and the resulting crisis of representation. In addition, the antagonistic type of politicization put forward by populist political actors seems to construct and perform the crisis in a particular (confrontational) way in a bid to represent marginalized popular demands and effect systemic change. Last but not least, this project is bound to face anti-populist reactions. Especially in times of crisis, when ruling elites fail to deal with economic frustration and social dislocation, allowing thus systemic inconsistencies to develop into a deep crisis of representation, calls for political radicalization are often and summarily denounced as 'populist' in a bid to limit a 'crisis in' develop into a 'crisis of'.

In this section we explore the populist character of movements against austerity and party formations representing them in Greece, namely SYRIZA. This is attempted in a way highlighting the dialectic between their dynamic emergence and the way in which economic and social dislocations were translated into a crisis of representation triggering the formation of particular (radical democratic and thus 
antagonistic) populist narrations of and solutions to the crisis, and, at the same time, stimulating anti-populist reactions. This case selection was not only based on the importance Greece has acquired throughout the European crisis as an experimental laboratory of socio-economic and political developments (Stavrakakis, 2013), with SYRIZA operating as the catalyst of a realignemnet of the collapsing party system around new political frontiers. In addition, and because of its populist profile, SYRIZA seems to have charted a path that other inclusionary forces are also partially following in the European South (Spain and Portugal) and beyond (the Corbyn and Sanders phenomena may not be completely unrelated). Operating at the antipodes of the dominant euro-centric model in populism research that often reduces populist politics to the extreme right, researching the Greek case may be pivotal in determining whether this new populist tide should be debated in terms of a historical anomaly or a slow and perhaps incoherent paradigm shift.

Having initially emerged as a marginal coalition of radical left parties and groups, SYRIZA has followed a process of organizational consolidation that, following its impressive results in the May and June 2012 elections (catapulting it from the $4,6 \%$ it received in 2009 to $26,8 \%$ ), has managed to come first with $36,4 \%$ of the vote in the 2015 elections, something that allowed its leader, Alexis Tsipras, to form a coalition government with the right-wing populist party ANEL (see Katsambekis 2015, 2016). Radically diverging from the euro-centric conventional wisdom which stereotypically casts populism as reactionary, nationalist, xenophobic, exclusionary and anti-European (see, for example, Berezin, 2009; Goodwin, 2011; Meijers, 2011; Painter, 2013), SYRIZA embraced the project of a politically integrated and solidary Europe, defended immigrants and socially marginalized sectors and pressed for a strong social rights agenda, claiming to fight for popular 
sovereignty, social justice and democratization (Spourdalakis, 2014; Stavrakakis and Katsambekis, 2014).

Such a project acquired salience against the background of the postdemocratic mutation of the post-transition regime in Greece (Metapolitefsi) and its dislocation. From 1974, when the dictatorship in Greece collapsed, onwards, a twoparty system prevailed in which New Democracy and PASOK, centre-right and centre-left, alternated in power. The policies of the two parties gradually converged, under conditions very similar to those encountered in other European cases, thus triggering a latent crisis of representation, already from the 1990s.

However, what dislocated the integrity of the system - obviously in a much more radical way in Greece than in Spain or Portugal - were the systemic failures associated with the 2008 global economic collapse and the way it has been adiministered by dominant elites (Kioupkiolis, 2014; Stavrakakis, 2013). During this period, in Greece, GDP contracted by $20 \%$ (between 2008 and 2012) and unemployment soared to $27 \%$ with youth unemployment reaching $60 \%$, prompting humanitarian concern (International Federation of Red Cross and Red Crescent Societies, 2013). It was, however, the management of these systemic failures by the established political class, provocatively described by Saskia Sassen as an 'economic version of ethnic cleansing' (Sassen, 2014, p. 36), which resulted in a wider intensification of social dislocations that deepened the indignation and discontent for the dominant regime of democratic representation (two party system) established after the transition to democracy, stimulating massive protest movements (including demonstrations, strikes and square occupations).

In this context, the role of the Greek Indignados (Aganaktismenoi) has been crucial (Pappas, 2014, p. 83). They constituted quite a massive but heterogeneous 
movement, convened on the basis of calls in the social media, inviting people to express its outrage against austerity, the established party system and the state of democratic representation (Katsambekis, 2014, pp. 180-184). The positions of the movement were marked by a distinct 'proto-populist' flavour: the people have been betrayed by the elites, which are to blame for the socio-economic collapse. As a result, the elites should not represent the people anymore and 'real' or 'direct' democracy should be sought (Prentoulis and Thomassen, 2013). Already in this discursive articulation the problem is given a particular meaning, blame is attributed and a future orientation is charted.

And yet, institutions have remained largely impervious to these demands allowing a 'crisis in' to develop into a 'crisis of' the system. At this juncture, certain social actors started searching for new vehicles of political representation that would overcome the fragmentation and the political impotence of the multitudes, organizing them and gaining access to power. Indeed, it was obviously impossible for the ensuing frustration, anger and despair to leave party identification and the political process untouched throughout a series of consecutive early elections (twice in 2012 and then in early 2015). The parties affected included those entrusted by the troika to implement tough austerity policies. Some of them have all but collapsed (like PASOK) with the main beneficiary being a former outsider, SYRIZA. SYRIZA thus emerged from the sidelines as a new mythical response to the crisis of political representation, as populism often does, a crisis it partly construed by attributing the blame for the socio-economic dislocation experienced since 2008 to the economic and political establishment (both national and European) in order to legitimize a populist redemocratization. 
Now, if SYRIZA - a party that previously exhibited no populist characteristics (Stavrakakis and Katsambekis, 2014, p. 127) - can now be designated as populist then this surely follows from the central role reserved for 'the people' within its crisis discourse as well as from the fact that it divides the social space into two opposing camps: 'them' (the 'establishment') and 'us' ('the people'), power and the underdog, the elite (domestic and European) and the non-privileged, those 'up' and the others 'down':

They have decided without us, so we are moving ahead without them. [...] NOW is the time to vindicate the struggles of our people, to punish and defeat the two-party system, to condemn the memoranda and the troika. [...] to create the conditions for an alternative governance, with the people in the leading role (SYRIZA, 2012, p. 1).

Within this dichotomic framework, blame for the crisis is attributed towards the 'external troika' (institutions like the IMF, the ECB and the European Commission) and its local 'collaborators', the so-called 'internal troika' (see, on this aspect, the relevant research of Stavrakakis and Katsambekis, 2014, p. 131). This narrative has been successful in articulating a variety of heterogeneous reactions and emotions against austerity into a new - retroactively and radically constructed - political subject ('the people in the leading role'), thus ascribing to SYRIZA's confrontational populism a hegemonic appeal. Thus, the 'proto-populism' of certain (anti-austerity) social movements was gradually transformed into party populism engaging with representation and representative institutions at a much deeper level.

\section{The anti-populist factor}


It is impossible to understand the turn of events in Greece and the salience acquired by populist discourses such as the one articulated by anti-austerity movements and taken up by SYRIZA in the context of the European crisis, without taking into account the broader environment within which it operated. This is clearly marked by the emergence and consolidation of a discursive frontier between populism and antipopulism, which influences the constitution of both fronts on the basis of their antithetical crisis narratives, of their antithetical political mythologies. In other words, the lack of meaning created by the social dislocations associated with the economic collapse and the implementation of the bail-out agreements has necessitated the supply of surfaces of inscription, of principles of intelligibility, allowing for a meaningful symbolization of the crisis, explaining its causes and sketching potential solutions. Not surprisingly, the populist framing has not been the only one on offer.

In the case of Greece, and due to the relatively long duration of the crisis and the international attention developments in the country have received, anti-populist discourses have created a deep discursive divide that on top of crosscuting Greek society has also acquired international salience. For example, in July 2012 Der Spiegel has reserved a prominent place for Tsipras within 'Europe's Ten Most Dangerous Politicians' precisely on these grounds: 'Reckless Rhetoric from Europe's Populists' (see, for more examples, ranging from the Guardian to the Financial Times, Stavrakakis and Katsambekis, 2014, p. 120). In the domestic context, it is clear that the radical politicization and antagonistic contestation staged and performed in SYRIZA's populist discourse, has created a vitriolic backlash denouncing SYRIZA's project as 'populist' in the most extreme pejorative sense of the term. If, in populist discourses, the 'people' operate as a positively charged empty signifier allowing the articulation of heterogeneous demands in a common political project, in anti-populist 
discourse, 'populism' functions like such an empty signifier, but this time a negatively charged one: as a discursive vessel capable of comprising an excess of heterogeneous meanings, operating as the synecdoche of an omnipresent evil and associated with irresponsibility, demagogy, immorality, corruption, destruction, and irrationalism (Stavrakakis, 2014, p. 509). In a book entitled Populism, Anti-populism and Crisis, Sevastakis and Stavrakakis have analyzed in depth this rampant anti-populist discourse that has dominated established parties and media in Greece. From former prime minister Samaras (leader of New Democracy) and former vice-premier Venizelos (leader of PASOK) to many journalists of mainstream media, the idea is that populism is eveywhere and constitutes perhaps the most grave danger for Greece and Europe (Stavrakakis, 2014, pp. 509-510).

Thus, in the discourse articulated by established parties against the newcomer SYRIZA, love of country was contrasted with the 'appearance of extremists and populists' (Samaras, 2013) with populism presented as 'the greatest enemy of Greece' (Hatzidakis, 2011). What is also striking is that this polarized anti-populist representation has remained at the forefront of anti-SYRIZA rhetoric even after the party's capitulation and the acceptance of a new memorandum with the troika. Hence, in November 2015 ex-prime minister Samaras castigated populism as a 'disease' (Samaras, 2015); no wonder that, upon congratulating the new leader of his party, the only thing he did stress was, once more, the need for New Democracy to unite in order 'to embrace all Greeks and win conclusively the battle against populism' (Samaras, 2016). But this was something that the new leader, Kyriakos Mitsotakis, had already highlighted in his acceptance speech: 'We have one goal. New Democracy must express all the forces in this land confronting the populism of an incompetent government' (Mitsotakis in Ta Nea, 2016). 
This extreme anti-populist rhetoric is not restricted within partisan political antagonism. It also marks the field of the media. Using qualitative and lexicometric methods, we have surveyed a series of corpora constructed on the basis of a total of 17,363 articles to which we had access, published in the Greek printed press between 1 June 2014 and 31 May 2015 (Nikisianis, Siomos, Stavrakakis and Dimitroulia, 2016). What emerges from this analysis is, once more, a clear division between ostensibly 'anti-populist' and 'pro-populist' media. What emerges as well is the polarization implicit in pro-populist discourse, but also the demonization of 'populism' (and the political forces denounced as populist, mainly SYRIZA) in the anti-populist press. Indeed, common adjectives marking references to populism in this camp comprise the following: extreme, vulgar, dangerous, cheap, fanatical, clientelist, catastrophic, unbearable, lumpen, irresponsible, savage, total, unscrupulous, etc. In a similar vein, a lot of metaphors utilized in forming sentences about populism emanate from medical discourse and associate it with some sort of illness, either of the body (contamination, plague, gangrene, cancer, etc.) or of the soul (madness, schizofreneia, irrationality, etc.). Another salient category of metaphors employed originate from the natural sciences, especially meteorology (tsunami, storm, etc.) and zoology, either real (parasite, wolfe, etc.) or imaginary (beast, monster, etc.). ${ }^{4}$

This discourse is far from restricted to fringe journalists and media; it constitutes a prominent feature of mainstream media and celebrity journalists. The case of Alexis Papachelas, singled out by the news portal Politico as one of the twenty eight people from twenty eight countries who are shaping, shaking and stirring Europe' is indicative (Politico, 2015). As editor-in-chief and leading columnist of the centre-right daily Kathimerini, Papachelas has published, throughout the last few years, numerous articles on populism invariably utilizing the metaphor of the 'beast'. 
Already from 2010 he refers to the 'beast of populism', to which in 2014 he will attribute all that has gone wrong in post-authoritarian Greece: 'All that angers us has an explanation and is not a momentary product, for it took several decades for the hungry beast of populism to rear its ugly head' (Papachelas, 2014). The repertoire of monstrosity will continue to feed this anti-populist discourse well into 2015 , when at least seven articles will be published utilizing this metaphor $(18 / 3 / 2015,12 / 7 / 2015$, 14/7/2015, 23/7/2015, 9/8/2015, 16/8/2015, 8/11/2015).

What should not escape our attention here is that, exactly like populist discourse, anti-populism is also flourishing on the ground of the crisis, only by constructing it in a very different way, attributing its causes to populism itself: in the Greek case, for example, to the dominance of a populist culture throughout metapolitefsi that corrupted democracy, excesively distributing democratic rights (Sevastakis, 2012, pp. 10-11, 15). In this sense, we see that whenever the problem of ascribing meaning arises, of representing deep economic and societal dislocations, different actors are bound to articulate opposing narratives attributing the blame to different forces and proposing alternative solutions. When the crisis takes on a form dismantling the established consensus on the institutions and legitimacy of democratic representation, extreme polarization is likely to emerge juaxtaposing different models of democracy, an elitist gouvérnement de Raison vs. a radical participatory one (Sevastakis, 2012, p. 29). In the ensuing discursive battle between populism and antipopulism, both sides performatively employ simplification of what is at stake and demonization of their enemy.

And this is something far from restricted to our case-study. The situation in Spain is very similar, with PODEMOS blaming 'la casta' for the crisis and mainstream media and politicians blaming PODEMOS on the basis of their 
irresponsible populism (Kioupkiolis, 2016). Outside Europe as well, in Venezuela for instance, the 2013 by-election has seen government and opposition employing 'equally strident' discourses claiming 'to embody the will of the Venezuelan people' against their 'corrupt' opponent (Hawkins, 2015). In addition, this point is valid not only at the synchronic but also at the diachronic level. Even the great - vitriolic critic of American agrarian populism of the 1890s, the person who is probably responsible for the pejorative connotations of populism in academic discourse, Richard Hofstadter, had accepted, in a self-critical gesture, that: 'If populist rhetoric, cited in isolation, sounds melodramatic, it is important to remember that an equally inflammatory rhetoric prevailed on the other side, in which the populists were portrayed as being at best deluded bumpkins and at worst primitives, demagogues, anarchists, and socialists' (Hofstadter, 1969, p. 19). Isn't it time to re-activate this long-forgotten insight? It always takes two to dance the populist/anti-populist tango.

\section{Conclusion}

Having briefly surveyed the literature on crisis and especially on its relevance for understanding populism, we have constructed a theoretical framework that draws on both main perspectives, one focusing on the importance of crises of political representation as external triggers of populism as well as another highlighting the need to take into account the performative staging of crisis as an internal feature of populist discursive constructions. We have tried to articulate both in a rigorous way, previously absent from populism research, by distinguishing between systemic failures (Real) and constructions of crisis (Symbolic), and yet registering at the same time the irreducible dialectic between the two. Moreover, this has allowed us to 
radically expand the scope of analysis to capture the crucial, but very often neglected, antithesis between populism and anti-populism.

Our focus on the recent and, as a result, under-researched example of SYRIZA has shown that more or less all the elements comprising such a theoretical framework are met in the empirical material. In the Greek case, socio-economic dislocations have trigerred a crisis of representation that facilitated the realignment of the party system, allowing a political actor like SYRIZA to hegemonize the field by performing a populist articulation of the crisis. Thus, all the different modalities of the relation between crisis and populism have been observed in ways vindicating a Laclauinspired negotiation between Real and Symbolic, dislocation and performative construction. Our analysis of the Greek case has also proved revealing in terms of demonstrating the need to always situate populist discursive constructions of crisis within the context of political antagonism. Would it be possible to adequately account for populist politics in Greece without taking into account the populism/anti-populism frontier? Without thematizing and researching anti-populist discourse? Without exploring its various sources, repertoires and blame attributions, especially its demonization of the beast of populism?

What thus emerges is a distinct political choreography connecting populism, anti-populism and crisis, able to facilitate a more comprehensive theorization of populist politics with broader analytical implications. In formal terms, this choreography could be presented as follows:

1. A deep economic and/or social dislocation is the necessary and yet insufficient starting point. 
2. When this dislocation is identified and highlighted as a 'crisis', it is often narrated in ways blaming particular causes and their agents at the level of representation (populists typically blame the 'establishment').

3. Simultaneously, a platform is articulated 'in the name of the people' to defend the victims of the crisis (the excluded, the impoverished, the underdog, the many).

4. This articulation triggers an anti-populist reaction (which is, very often, the one designating as 'populist' those claiming to speak on behalf of 'the people').

5. Both discourses emerging (populist and anti-populist) can, in principle, acquire a left-wing (inclusionary, egalitarian, participatory) or right-wing profile (exclusionary, elitist) and both employ simplification and demonization, often leading to the establishment of a polarized political culture. At any rate, it is impossible to adequately study populism without inquiring into anti-populism and vice-versa. ${ }^{5}$

Needless to say, many issues related to our argument remain to be explored and further debated. How are crises eventually - even partially and/or temporarily resolved and how does the dialectic between Real and Symbolic overdetermine such resolutions, vindicating or frustrating populist and anti-populist diagnoses and promises? What is the exact status of the populism/anti-populism antithesis? Does it constitute, for example, an emerging cleavage? In what sense? In which contexts? Is the polarization introduced and cultivated both by many populist discourses and de facto emerging through the populism/anti-populism divide always a danger or can it also function as a corrective for representative democracy under conditions of postdemocratic mutation? In terms of the current European crisis, is a new paradoxical compromise between elitist and participatory forces in sight or will the intensification of the opposition between the two trends threaten to destabilize the future of the 
European project? All these are open questions. Hopefully, the argumentation put forward in this paper will help future attempts to illuminate them. 


\section{Notes}

1. This is by no means to argue that Laclau should be exclusively evaluated as a 'theorist of populism'. Nevertheless, it was the (political and intellectual) challenges resulting from the Peronist experience that triggered his turn to Althusserianism (Laclau, 1990, pp. 198-9), initiating his whole theoretical trajectory. Then, in the 1970s, it was Laclau himself that gave the title 'Towards a Theory of Populism' to one of his first major theoretical contributions (Laclau, 1977), something that was to be repeated several times up until the publication of The Populist Reason in 2005 (Laclau, 2005a). Indeed populism seems to have functioned throughout his career both as a challenge for strategic analysis and as an inspiration for theoretical and conceptual innovation.

2. Although completely and paradoxically ignored in Moffitt's early work, this aspect of Laclau's contribution is thoroughy acknowledged in his newly published book (Moffitt, 2016, p. 40).

3. It may initially seem that highlighting the antagonism between populist and antipopulist forces contradicts Laclau's assertion that populism is ultimately synonymous with politics (Laclau, 2005b, p. 13). And yet, even according to his own abstract/formal statement, politics (that is to say populism) does not exhaust the totality of our experience: 'We have an end of politics when the community conceived as a totality, and the will representing that totality, become indistinguishable from each other. In that case, as I have argued throughout this essay, politics is replaced by administration and the traces of social division disappear' (Laclau, 2005b, p. 48). Anti-populism, in the sense utilized in our paper, encompasses post-democraric discourses that would ideally replace politics with technocratic administration - what, in other words, constitutes populism's 'constitutive outside'. 
This is also consistent with the basic distinction introduced in Hegemony and Socialist Strategy between the logics of equivalence and difference (Laclau and Mouffe, 1985).

Of course, in political reality, both abstract positions - pure populism and pure administration - are ultimately impossible and thus populism is always articulated with some sort of (differential) institutional logic in the making while anti-populism often acquires a confrontational (equivalential) character, incorporating peripheral populist elements and adopting a quasi-populist style. However, contra Laclau, we would argue that this mutual contamination does not justify the implicit degreeism to use a diagnostical term introduced by Sartori - contaminating Laclau's argument in this particular text: there is a point when, to use an old cliché, quantitative gradation becomes qualitative difference, when an antagonism between a political discourse claiming to represent a frustrated popular will and an administrative discourse aggressively justifying this frustration is crystallized along the lines of a populism/anti-populism frontier - otherwise, what is lost is the conceptual particularity of populism as a tool for concrete political analysis in the register of hegemony (Stavrakakis, 2004, p. 263).

If certain slippages in Laclau's discourse seem to allow for the articulation of a set of different and even antithetical possibilities in theorizing the relationship between hegemony, politics and populism, it seems clear enough that the most theoretically consistent and analytically suggestive option is to understand populism as 'a species of the genus hegemony, the species that calls into question the existing order with the purpose of constructing another (122-3). This genus has at least one other species, institutionalist [anti-populist] discourse, whose essence is to maintain the status quo' (Arditti, 2010, pp. 492-3).

4. For similar metaphors utilized on the populist side, see Moffitt, 2015, p. 201. 
5. This model could be used in conjunction with that introduced by Moffitt as it helps to situate the latter within the broader frame of political antagonism and hegemonic struggle (Moffitt, 2015, pp 198; 2016, p. 121).

\title{
Acknowledgment
}

This article has been composed within the context of the 'POPULISMUS: Populist Discourse and Democracy' research project (2014-5). POPULISMUS has been implemented at the School of Political Sciences of the Aristotle University of Thessaloniki within the framework of the Operational Program 'Education and Lifelong Learning' (Action 'ARISTEIA II') and was co-funded by the European Social Fund (European Union) and Greek national funds (project no. 3217). More information is accessible from the POPULISMUS Observatory: www.populismus.gr. Many thanks are due to Ioanna Garefi for her technical support.

\begin{abstract}
About the authors
Yannis Stavrakakis is Professor of Political Discourse Analysis at the Aristotle University of Thessaloniki. He was Principal Investigator of the POPULISMUS research project (2014-5) and is co-convener of the Populism Specialist Group of the Political Studies Association. His work focuses on psychoanalytic and discursive political theory and on the analysis of populist and anti-populist discourses. Previous books include Lacan and the Political (Routledge, 1999) and The Lacanian Left (State University of New York, 2007). His forthcoming book with Palgrave is entitled The Populist Scandal and he is also currently editing the Routledge Handbook of Psychoanalytic Political Theory.
\end{abstract}


Giorgos Katsambekis was a POPULISMUS doctoral researcher and is currently a post-doctoral researcher in the School of Political Sciences at the Aristotle University of Thessaloniki. His research interests include contemporary political theory, discourse analysis, populism, social movements and Europe's radical left. His work has appeared in the Journal of Political Ideologies, European Political Science, Constellations, The Political Quarterly, Political Studies Review. He recently coedited the volume Radical Democracy and Collective Movements Today (Ashgate, 2014).

Alexandros Kioupkiolis is Assistant Professor of Contemporary Political Theory at the Aristotle University of Thessaloniki and was a researcher within the scope of the POPULISMUS project. His research interests lie in modern philosophies of freedom, contemporary philosophies of justice, theories of democracy, the analysis and critique of power. Recent publications include: the edited volume Radical Democracy and Collective Movements Today (Ashgate, 2014); the monographs Freedom After the Critique of Foundations: Marx, Liberalism and Agonistic Autonomy (PalgraveMacmillan, 2012) and The Commons of Freedom (Exarchia Editions, 2014).

Nikos Nikisianis has a natural sciences background and his $\mathrm{PhD}$ thesis involved a discursive analysis of the ideological dimensions of biodiversity in scientific ecology. He was a POPULISMUS post-doctoral researcher and has published on the politics of ecology, populist discourse and the media.

Thomas Siomos is a journalist and is currently completing his doctorate on the political and psycho-social implications of crisis discourse at the School of Political 
Sciences of the Aristotle University of Thessaloniki. He was a POPULISMUS doctoral researcher and is currently coordinating the POPULISMUS Observatory.

\section{References}

Arditti, Benjamin (2010) 'Populism is Hegemony is Politics? On Ernesto Laclau's On Populist Reason'. Constellations 17(3): 488-497.

Berezin, M. (2009) Illiberal Politics in Neoliberal Times. Cambridge: Cambridge University Press.

Bourdieu, P. (1991) Language and Symbolic Power. Cambridge: Polity.

Canovan, M. (1999) 'Trust the People! Populism and the Two Faces of Democracy'. Political Studies XLVII: 2-16.

Connolly, W. (1991) Identity/Difference: Democratic Negotiations of Political Paradox. Ithaca: Cornell University Press.

Crouch, C. (2004) Post-Democracy. Cambridge: Polity.

Dahl, R. (2006) A Preface to Democratic Theory. Chicago: University of Chicago Press.

Goodwin, M. (2011) Right Response: Understanding and Countering Populist Extremism in Europe. London: Chatham House.

Gramsci, A. (1971) Selections from the Prison Notebooks of Antonio Gramsci. London: Lawrence and Wishart.

Hay, C. (1995) 'Narratives of the New Right and Constructions of Crisis'. Rethinking Marxism 8(2). (1999) 'Crisis and the Structural Transformation of the State'. British Journal of Politics and International Relations 1(3): 317-344. 
Hatzidakis, K. (2011) 'Populism is the Greatest Enemy of Greece'. Interview to Aris Ravanos, To Vima tis Kyriakis, http://www.tovima.gr/politics/

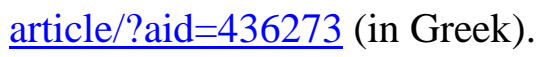

Hawkins, K. (2015) 'Venezuela'. Entry for the POPULISMUS Observatory interactive map, http://observatory.populismus.gr/map

Hofstadter, R. (1969) 'North America', in Ghita Ionescu \& Ernest Gellner (eds) Populism: Its Meanings and National Characteristics. London: Weidenfeld \& Nicholson.

Jessop, B. (2015) 'The Symptomatology of Crises, Reading Crises and Learning from Them: Some Critical Realist Reflections'. Journal of Critical Realism 14(3): $238-271$.

Katsambekis, G. (2014a) 'The Multitudinous moment(s) of the People: Democratic agency disrupting established binarisms'. In Kioupkiolis, A. and Katsambekis, G. (eds) Radical Democracy and Collective Movements Today. The Biopolitics of the Multitude versus the Hegemony of the People. Farnham: Ashgate: 169-190. (2014b) 'The Place of the People in Post-Democracy. Researching “Antipopulism” and Post-Democracy in Crisis-Ridden Greece'. Revista POSTData, 19(2): 555-582. (2015) 'A Government of the Left in Greece: The Coalition of

SYRIZA with ANEL and What Lies Ahead'. LeftEast, 30 January, http://goo.gl/TPf2SB (2016) 'Radical Left Populism in Contemporary Greece: Syriza's Trajectory from Minoritarian Opposition to Power', Constellations, early view, doi: 10.1111/1467-8675.12234. 
Kioupkiolis, A. (2014) 'Towards a Regime of Post-political Biopower? Dispatches from Greece, 2010-2012'. Theory, Culture and Society 31(1): 143-158. (2016) 'PODEMOS: The Ambiguous Promises of Left-wing

Populism in Contemporary Spain’. Journal of Political Ideologies 21(2): 99120.

Knight, A. (1998) 'Populism and Neo-populism in Latin America, Especially Mexico'. Journal of Latin American Studies 30(2).

Koselleck, R. (1988) Critique and Crisis: Enlightenment and the Pathogenesis of Modern Society. Cambridge, Mass.: The MIT Press.

Laclau, E. (1977) ‘Towards a Theory of Populism', Politics and Ideology in Marxist Theory: Capitalism, Fascism, Populism. London: New Left Books: 143-199. (1990) New Reflections on the Revolution of our Time. London: Verso. (1996) Emancipation(s). London: Verso. (2003) 'Discourse and Jouissance: A Reply to Glynos and Stavrakakis', Journal for Lacanian Studies , 1(2): 278-85.

(2004) 'Glimpsing the Future: A Reply', in Simon Critchley and

Oliver Marchart (eds) Laclau: A Critical Reader, London: Routledge: 279-328. (2005a) On Populist Reason. London: Verso. (2005b) ‘Populism: What's in a Name?', in F. Panizza (ed.) Populism and the Mirror of Democracy, London: Verso.

Laclau, E. and Mouffe, C. (1985) Hegemony and Socialist Strategy. London: Verso. Meijers, E. (ed.) (2011) Populism in Europe. Vienna: Green European Foundation. Moffitt, B. (2015) 'How to Perform Crisis: A Model for Understanding the Key Role of Crisis in Contemporary Populism'. Government and Opposition 50(2): 189217. 
(2016) The Global Rise of Populism: Performance, Political Style,

Representation, Stanford: Stanford University Press.

Moffitt, B. and Tormey, S. (2014) 'Rethinking Populism: Politics, Mediatisation and Political Style'. Political Studies 64: 381-397.

Mouffe, C. (2000) The Democratic Paradox. London: Verso.

Mudde, C. and Rovira Kaltwasser, C. (2012a) 'Populism and (Liberal) Democracy: A Framework for Analysis'. In Mudde, C. and Rovira Kaltwasser, C. (eds) Populism in Europe and the Americas: Threat or Corrective for Democracy?. Cambridge: Cambridge University Press: 1-26.

(2013b) 'Exclusionary vs. Inclusionary Populism: Comparing

Contemporary Europe and Latin America'. Government and Opposition 48(2): $147-174$

Nikisianis, N., Siomos, Th., Stavrakakis, Y. and Dimitroulia, T. (2016) 'Populism vs. Anti-populism in the Greek Press, 2014-5'. Synchrona Themata 132-3: 52-70.

Ostiguy, P. (2009) 'The High and Low in Politics: A Two-dimensional Political Space for Comparative Analysis and Political Studies'. Working Paper \# 360, Kellogg Institute.

Painter, A. (2013) Democratic Stress, the Populist Signal and the Extremist Threat. London: Policy Network.

Papachelas, A. (2014) 'Falling Prey to the Beast of Populism', Kathimerini, http://www.ekathimerini.com/160654/article/ekathimerini/comment/fallingprey-to-the-beast-of-populism

Pappas, T. (2014) Populism and Crisis Politics in Greece. Abingdon: Palgrave Macmillan.

Perezous, K. (2007) History of 'Crisis': From Ancent Medicine to the Political 
Discourse of Modernity, PhD thesis. Athens: University of Athens.

Politico, 'The Twentyeight People from Twentyeight Countries who are Shaping, Shaking and Stirring Europe', http://www.politico.eu/list/politico-28/

Prentoulis, M. and Thomassen, L. (2013) 'Political theory in the square: Protest, representation and subjectification'. Contemporary Political Theory 12(3): 166-184.

Rancière, J. (2006) The Hatred for Democracy. London: Verso.

Roberts, K. (1995) 'Neoliberalism and the Transformation of Populism in Latin America: The Peruvian Case'. World Politics 48(1): 82-16. (2012) 'Populism and Democracy in Venezuela under Hugo Chavez'.

In C. Mudde and C. Rovira Kaltwasser (eds) Populism in Europe and the Americas: Threat or Corrective for Democracy?. New York: Cambridge University Press: 136-59.

(2015) 'Populism, Political Mobilizations, and Crises of Political Representation'. In de la Torre, Carlos (ed.) The Promise and Perils of Populism. Lexington: The University Press of Kentucky: 140-158.

Samaras, A. (2013) 'Samaras from Brussels against extremists and populists', http://www.protothema.gr/news-in-english/article/319690/samaras-frombrussels-against-extremists-and-populists/ (2015) 'Populism is a disease that leads to disasters', 2 November 2015, http://www.larazon.es/internacional/antonis-samaras-populism-is-a-diseasethat-leads-to-disasters-FB11100005\#Ttt1UkBvuO6VTECe (2016) 'Samaras: ND united to Win the Battle Against Populism', http://www.kathimerini.gr/845238/article/epikairothta/politikh/samaras-h-ndenwmenh-na-kerdisei-th-maxh-kata-toy-laikismoy (in Greek) 
Sassen, S. (2014) Expulsions: Brutality and Complexity in the Global Economy.

Cambridge, MA: The Belknap Press.

de Saussure, F. (1959) Course in General Linguistics. New York: Philosophical Library.

Schumpeter, J. (2003) Capitalism, Socialism and Democracy. London: Routledge.

Sevastakis, N. (2012) “ "Contemporary Anti-populism”: From Political Pathology to Cultural Evil'. In Sevastakis, N. and Stavrakakis, Y., Populism, Anti-populism and Crisis. Athens: Nefeli: 9-41.

Spourdalakis, M. (2014) 'The Miraculous Rise of the "Phenomenon SYRIZA"'. International Critical Thought 4(3): 354-366.

Stavrakakis, Y. (2004) 'Antinomies of Formalism: Laclau's Theory of Populism and the Lessons from Religious Populism in Greece', Journal of Political Ideologies, 9(3): 253-267.

(2007) The Lacanian Left, Albany: SUNY Press.

(2013) 'Dispatches from the Greek Lab: Metaphors, Strategies and

Debt in the European Crisis'. Psychoanalysis, Culture and Society 18(3): 313324. (2014) 'The Return of "the People": Populism and Anti-Populism in the Shadow of the European Crisis'. Constellations 21(4): 505-517.

Stavrakakis, Y. and Katsambekis, G. (2014) 'Left-wing Populism in the European Periphery: The Case of SYRIZA'. Journal of Political Ideologies 19(2): 127129.

Sum, Ngai-Ling \& Jessop, B. (2013) Towards a Cultural Political Economy. Cheltenham: Edward Elgar.

SYRIZA (2012), 'Electoral Declaration’, www.syn.gr/ekl2012/eklogikidiak2012.pdf 
Taggart, P. (2000) Populism. Buckingham: Open University Press.

de la Torre, C. (2015) 'Introduction: Power to the People? Populism, Insurrections, Democratization'. In Carlos de la Torre (ed.) The Promise and the Perils of Populism. Lexington: Kentucky University Press: 1-28.

de la Torre, C. and Arnson, C. (2013) 'Introduction: The Evolution of Latin American Populism and the Debates Over its Meaning'. In de la Torre, C. and. Arnson, C. (eds) Latin American Populism in the Twenty-First Century. Baltimore, MA: The Johns Hopkins University Press: 1-35. 